\title{
Discoloration of surface sealants by plaque disclosing solution
}

\author{
Sinan Şen ${ }^{1}$ (I) · Ralf Erber ${ }^{1} \cdot$ Gözde Şen ${ }^{2}$ Nadine Deurer ${ }^{1}$ Sebastian Zingler ${ }^{1} \cdot$ Christopher J. Lux $^{1}$
}

Received: 2 October 2019 / Accepted: 28 February 2020 / Published online: 6 May 2020

(c) The Author(s) 2020

\begin{abstract}
Purpose Surface sealants are widely used as a prevention strategy and are indicated for young patients with insufficient oral hygiene who also need plaque removal by professional tooth cleaning. The aim of this study was to evaluate discoloration of surface sealants by plaque disclosing solutions and to test to what extent this discoloration can be reduced again by professional tooth cleaning.

Methods In all, 96 extracted lesion-free human teeth were randomly assigned to treatment with either Pro Seal ${ }^{\circledR}$ (PS; Opal Orthodontics, South Jordan, UT, USA) or Opal ${ }^{\circledR S}$ eal $^{\mathrm{TM}}$ (OS; Reliance Orthodontic Products, Itasca, IL, USA). Color evaluations after application of the plaque disclosing solution Mira-2-Ton ${ }^{\circledR}$ (Hager \& Werken, Duisburg, Germany) were performed using a clinical spectrophotometer. Staining and polishing were repeated once. Color differences $(\Delta \mathrm{E})$ above 3.77 were regarded as clinically relevant.

Results All sealants showed high, clinically relevant $\Delta \mathrm{E}$ values after the first staining. Polishing led to significantly decreased $\Delta \mathrm{E}$ values on PS-treated teeth; however, the median $\Delta \mathrm{E}$ value remained above the clinically relevant threshold. Polishing on OS-treated teeth only slightly reduced $\Delta \mathrm{E}$ values. After professional tooth cleaning both PS and OS showed clinically relevant $\Delta \mathrm{E}$ values.

Conclusion Surface sealants show clinically relevant discoloration after exposure to plaque disclosing solution under in vitro conditions. Such discolorations could not be removed by professional tooth cleaning. Thus, in clinical practice, plaque disclosing solutions might cause esthetic deficits in surface sealant-treated teeth. The impact of plaque disclosing solutions under clinical conditions (e.g., in the presence of saliva and by various aspects of a person's nutrition) should be investigated in clinical studies.
\end{abstract}

Keywords Orthodontic treatment $\cdot$ Discoloration $\cdot$ Surface sealants $\cdot$ Staining $\cdot$ Tooth cleaning

\section{Verfärbung von Glattflächenversieglern durch Plaquefärbelösung}

\section{Zusammenfassung}

Zielsetzung Glattflächenversiegler werden häufig als Präventionsstrategie eingesetzt und sind für junge Patienten mit unzureichender Mundhygiene indiziert, die auch Plaqueentfernung durch professionelle Zahnreinigung benötigen. Ziel der Studie war es, die Verfärbung von Glattflächenversieglern durch Plaquefärbelösung zu evaluieren und zu prüfen, inwieweit diese Verfärbung durch professionelle Zahnreinigung wieder reduziert werden kann.

Sinan Şen

sinan.sen@med.uni-heidelberg.de

1 Department of Orthodontics and Dentofacial Orthopaedics, Dental School, University of Heidelberg, Im Neuenheimer Feld 400, 69120 Heidelberg, Germany

2 MVZ Dentale Praxisklinik, Dr. Dilling \& Kollegen GmbH, Fleiner Straße 3, 74072 Heilbronn, Germany 
Methoden Insgesamt 96 extrahierte läsionsfreie humane Zähne wurden nach dem Zufallsprinzip der Behandlung mit Pro Seal $^{\circledR}$ (PS; Opal Orthodontics, South Jordan, UT, USA) oder Opal ${ }^{\circledR S}$ Seal ${ }^{\mathrm{TM}}$ (OS; Reliance Orthodontic Products, Itasca, IL, USA) zugeordnet. Die Farbbestimmungen nach Anwendung der Mira-2-Ton ${ }^{\circledR}$ (Hager \& Werken, Duisburg, Deutschland) Plaquefärbelösung wurden mit einem klinischen Spektrophotometer durchgeführt. Färbung und Politur wurden noch einmal wiederholt. Farbunterschiede $(\Delta \mathrm{E})$ über 3,77 wurden als klinisch relevant angesehen.

Ergebnisse Alle Versiegelungen zeigten hohe, klinisch relevante $\Delta$ E-Werte nach der ersten Färbung. Das Polieren führte zu signifikant verringerten $\Delta \mathrm{E}$-Werten bei den mit PS behandelten Zähnen; der Medianwert von $\Delta \mathrm{E}$ blieb jedoch über dem klinisch relevanten Schwellenwert. Das Polieren auf OS-behandelten Zähnen reduzierte die $\Delta$ E-Werte nur geringfügig. Nach der professionellen Zahnreinigung zeigten sowohl PS als auch OS klinisch relevante $\Delta$ E-Werte.

Schlussfolgerungen Glattflächenversiegler zeigen klinisch relevante Verfärbungen nach Anwendung der Plaquefärbelösung unter In-vitro-Bedingungen. Solche Verfärbungen konnten durch eine professionelle Zahnreinigung nicht entfernt werden. In der klinischen Praxis können Plaquefärbelösungen daher zu ästhetischen Defiziten bei mittels Glattflächenversieglern behandelten Zähnen führen. Die Auswirkungen von Plaquefärbelösungen unter klinischen Bedingungen (z. B. in Anwesenheit von Speichel, unterschiedliche Aspekte von jeweils aufgenommenen Nahrungsmitteln) sollten in klinischen Studien untersucht werden.

Schlüsselwörter Kieferorthopädische Behandlung · Verfärbung · Glattflächenversiegler · Anfärben · Zahnreinigung

\section{Introduction}

Enamel surface sealants are widely used in orthodontic practice to avoid enamel decalcifications in patients treated with fixed orthodontic appliances [6, 16, 21]. These sealants are indicated especially for patients with insufficient oral hygiene who are more likely to present with plaque and tooth stains. Dental plaque and stains on teeth with brackets require periodical removal by professional tooth cleaning (PTC). As a prophylactic measure during orthodontic treatment with fixed appliance, PTC should be performed every 3-6 months depending on the individual oral hygiene status [13].

Plaque disclosing solutions [3, 15, 18] are often used to support monitoring of the personal oral hygiene by the dentist, for instance, before performing PTC, or by patients to improve oral hygiene by self-checking the efficiency of daily tooth brushing [14].

A commonly used disclosing agent is the two-tone erythrosine-free disclosing dye solution Mira-2-Ton ${ }^{\circledR}$ (Hager \& Werken, Duisburg, Germany), which can help to distinguish blue-dyed (brilliant blue FCF, E133, color index 42090) older plaque from pink-dyed (phloxine B, color index 45410) newer plaque [17, 18]. A possible staining effect of such disclosing solutions on orthodontic surface sealant cannot be excluded. However, so far only one study evaluated a possible staining effect of dyes used in disclosing solutions on dental materials. The authors found a very slight blue discoloration of resin composites after the use of a Colgate mouthwash, containing low concentrations of brilliant blue (E133) [7, 12]. Presently there are no studies on color changes of dental materials after the use of plaque disclosing solutions.
Orthodontic surface sealants, as we already recently showed in an in vitro study on four orthodontic surface sealants of different chemical compositions, are prone to discoloration by certain foods and beverages. Polishing with brush and prophy paste for $5 \mathrm{~s}$ reduced color changes; the original tooth color, however, could not be restored even after long polishing times (15s) [5].

In particular in patients requiring frequent PTC involving the use of plaque disclosing solutions, the susceptibility of orthodontic surface sealants to discoloration could impair esthetics.

To our knowledge, there are currently no data available on the discoloration of orthodontic surface sealants after exposure of plaque disclosing solutions. Therefore, the aim of this study was to evaluate two different surface sealants for their discoloration by a plaque disclosing solution. Thus, the null hypothesis was that plaque disclosing solutions do not lead to a significant discoloration of orthodontic surface sealants or can be sufficiently removed by professional tooth cleaning.

\section{Methods}

\section{Orthodontic surface sealants}

Two frequently used surface sealants based on different chemical compositions were evaluated in this study: (1) the composite-based $18 \%$ filled sealant Pro Seal ${ }^{\circledR}$ (Opal Orthodontics, South Jordan, UT, USA, Lot No. 152740) and (2) the glass ionomer-based nanoparticle $38 \%$ filled sealant $\mathrm{Opal}^{\circledR} \mathrm{Seal}^{\mathrm{TM}}$ (Reliance Orthodontic Products, Itasca, IL, USA, Lot No. BDBRJ). 


\section{Sample preparation and group allocation}

The workflow of the study is depicted in Fig. 1. In this in vitro study, 96 extracted lesion-free human teeth (48 incisors and 48 premolars) were randomly assigned to treatment with either Pro Seal ${ }^{\circledR}$ or $\mathrm{Opal}^{\circledR} \mathrm{Seal}^{\mathrm{TM}}$ (48 per group). Randomization was done manually by drawing teeth from an opaque container by a person without dental knowledge. Teeth crowns were separated using a diamond cutting disc (946.104.180 Komet Medical, Gebr. Brasseler GmbH \& Co KG, Lemgo, Germany) and then embedded in silicone impression material (Silikon Knetmasse, Omnident DentalHandelsgesellschaft GmbH, Germany).

All sealants were applied according to the manufacturers' instructions. Light curing was performed using a bluephase ${ }^{\circledR}$ G2 polymerization lamp (Ivoclar Vivadent AG, Schaan, Liechtenstein); luminosity was routinely tested and found to be above $1200 \mathrm{~mW} / \mathrm{cm}^{2}$.

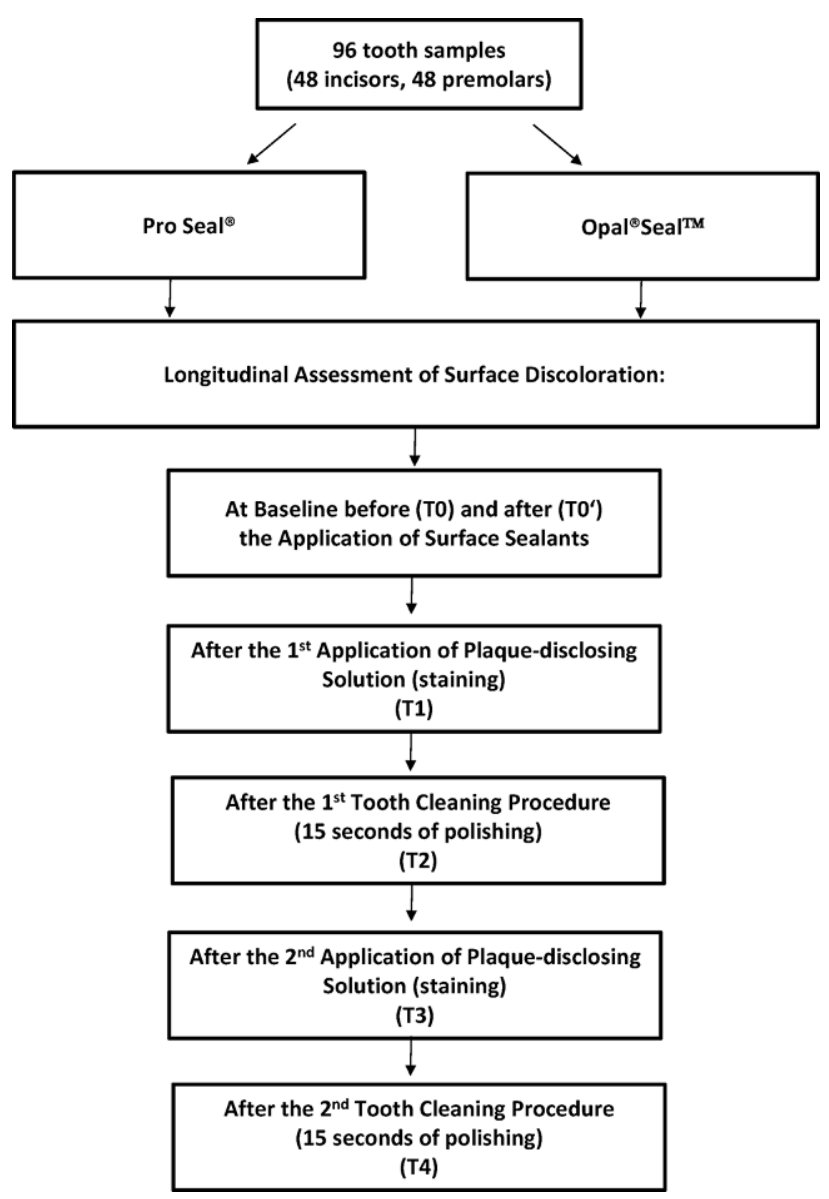

Fig. 1 Workflow of the study

Abb. 1 Ablauf der Studie

\section{Application of disclosing solution}

Two-tone erythrosine-free plaque disclosing dye solution Mira-2-Ton ${ }^{\circledR}$ (Hager \& Werken, Duisburg, Germany) was used according to manufacturer's instructions at room temperature (mean temperature $20^{\circ} \mathrm{C}$ ). Five seconds after application, excess plaque disclosure solution was removed with a suction cup and the tooth surface was rinsed with water for $5 \mathrm{~s}$ (Fig. 2). Hereafter the application of plaque disclosing solution will be referred to as "staining".

\section{Color measurement}

Color measurements were performed by use of a clinical spectrophotometer (Easyshade V, Vita Zahnfabrik, Bad Säckingen, Germany) which has been proven to be reliably suitable for laboratory and clinical use. To obtain high quality measurement, the device was centered on the geometric mid zone of the labial tooth surface and measurements were performed as triplicates on each tooth at each time point. Color data were collected and converted to $\mathrm{L}^{*}$, $\mathrm{a}^{*}$, and $\mathrm{b}^{*}$ values according to the Commission Internationale de l'E' clairage (CIE) by the results of intraoral spectrometer. Color differences $(\Delta \mathrm{E})$ were calculated from $\mathrm{L}^{*}, \mathrm{a}^{*}$, and $b^{*}$ values using the following equation [2]:

$\Delta E_{a b}=\sqrt{\left(L_{1}-L_{2}\right)^{2}+\left(a_{1}-a_{2}\right)^{2}+\left(b_{1}-b_{2}\right)^{2}}$

In the literature, different threshold values were discussed to describe clinically relevant changes, e.g., $\Delta \mathrm{E}=2$ or $\Delta \mathrm{E}=2.72$. Based on the study of Johnston et al. [8] and as in our previous work we used threshold value of $\Delta \mathrm{E}=3.7$ [5].

\section{Polishing with brush and prophy paste}

After each staining, polishing was performed at 2600 rotations/min with vertical loads of $1.5 \mathrm{~N}$ monitored with a precision balance according to Zimmer et al. [20]. Each polishing was done with a brush (Hawe Miniature Cleaning \& Polishing Brushes, KerrHawe, Bioggio, Switzerland) and ready-made, fluoridated prophy paste $\left(\mathrm{Cleanic}^{\circledR}{ }^{\circledR}\right.$, KerrHawe, Bioggio, Switzerland, Lot No. 135145-09-'15) with low abrasiveness $(\mathrm{RDA}=27)$ for $15 \mathrm{~s}$ using a low-speed handpiece (Sirona Dental System, Bensheim, Germany).

\section{Longitudinal assessment of surface color}

Each sample was evaluated after the application of surface sealant (T0', baseline), after the first staining (T1), after the first polishing for $15 \mathrm{~s}$ (T2), after the second staining (T3) and after the second polishing for $15 \mathrm{~s}$ (T4). We chose $15 \mathrm{~s}$ of polishing time because we showed in our previous work 
Fig. 2 Application of plaque disclosing solution

Abb. 2 Anwendung der Plaquefärbelösung

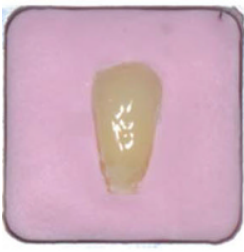

Baseline (treated with surface selant)

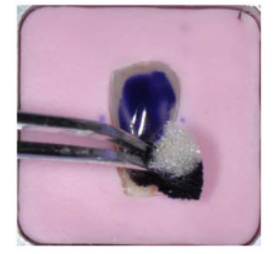

Application of disclosing solution for 5 seconds

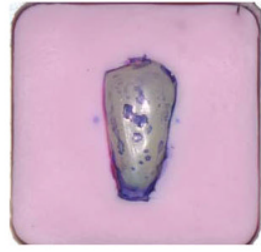

Removal of excess solution with a suction cup

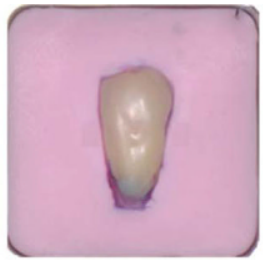

After water rinsing for $\mathbf{5}$ seconds that color changes obtained after $15 \mathrm{~s}$ of polishing were more distinct than that after $5 \mathrm{~s}$, albeit not significant [5].

\section{Statistics and methods}

The sample size calculation was based on expected $\Delta \mathrm{E}$ changes. As in our previous work we used a threshold value of $\Delta \mathrm{E}=3.77$. Within this previous study, a standard deviation of 5.9 for $\Delta \mathrm{E}$ was measured [5]. A $\Delta \mathrm{E}$ threshold of 3.77 , assuming a common standard deviation of 5.9 using a two-group test with a 0.05 two-sided significance level and a power of 0.80 yielded a sample size of 40 per group, we added $20 \%$ for potential dropouts. Thus, 48 teeth per group were evaluated.

Data from all investigations were collected and descriptive statistics was performed (mean, standard deviation). Changes in color after the above mentioned conditions were analyzed with the Mann-Whitney $\mathrm{U}$ test due to their skewed distribution. Two-sided $p$ values $<0.05$ were considered statistically significant. No multiplicity adjustment was applied, and all $p$ values should be interpreted descriptively. The data were processed using SigmaPlot 12.0 software (Systat Software, Inc., San Jose, CA, USA).

\section{Results}

The main objective of this study was to measure the staining effect of the two-tone erythrosine-free plaque disclosing dye solution Mira-2-Ton ${ }^{\circledR}$ on two orthodontic surface sealants longitudinally on extracted teeth.

\section{Clinically relevant (visible) color changes after application of plaque disclosing solution}

Longitudinal color assessment revealed visible color changes, especially after the first staining of Pro Seal ${ }^{\circledR}$-treated teeth (T1), and the second staining (T3) and second polishing (T4) of both surface sealants. Exemplary sample photographs are depicted in Fig. 3.

\section{Color changes of the individual surface sealants within the sealant group}

The means of $\mathrm{L}^{*}, \mathrm{a}^{*}, \mathrm{~b}^{*}$ and $\Delta \mathrm{E}$ values ( \pm standard deviation) for baseline after the application of surface sealant and staining and polishing conditions on sealed tooth surfaces are given in the Table 1. Additionally, the mean color changes ( $\Delta E$ values) for each sealant group are depicted as box plots in Fig. 4.

Staining of Pro Seal ${ }^{\circledR}$-treated teeth caused clinically relevant changes of $\Delta \mathrm{E}$ values. These were significantly reduced by polishing for $15 \mathrm{~s}$ after the first staining (T1 vs. T2) but remained above the clinically relevant threshold level. The second staining also caused significant increases of $\Delta \mathrm{E}$ values which could be significantly reduced by polishing ( $\mathrm{T} 3$ vs. T4); again $\Delta \mathrm{E}$ values remained above the clinically relevant threshold level. Compared to baseline (T0'), color changes at all staining and polishing time points (T1-T4) were above the clinically relevant threshold level $(\Delta \mathrm{E}=3.77)$ and caused visible esthetic deficits (Fig. 4a).

Overall, Opal ${ }^{\circledR} S e a l^{\mathrm{TM}}$-treated teeth exhibited a lesser degree of discoloration after both stainings than Pro Seal ${ }^{\circledR}$ treated teeth. Polishing was not able to reduce color changes significantly at both time points ( $\mathrm{T} 1 \mathrm{vs}$. Ts and $\mathrm{T} 3 \mathrm{vs}$. T4). However, due to the lesser extent of discoloration after the first staining, the first polishing was able to reduce $\Delta \mathrm{E}$ values below the clinically relevant threshold $(\Delta \mathrm{E}=3.77)$. Importantly, the degree of discoloration appeared to increase from the first to the second staining, and $\Delta \mathrm{E}$ values were significantly higher after the second polishing compared to the first polishing. Taken together, as with Pro Seal ${ }^{\circledR}$-treated teeth, compared to baseline (T0') color changes at most staining and polishing time points (T1, T3 and T4) were above the clinically relevant threshold level. Opal ${ }^{\circledR} S e a{ }^{\mathrm{TM}}$ treated teeth revealed a lesser degree of discoloration compared with Pro Seal ${ }^{\circledR}$-treated teeth but the significant increase of $\Delta \mathrm{E}$ values from $\mathrm{T} 2$ (after first polishing) to $\mathrm{T} 4$ (after second polishing) suggests that there might be a progressive increase of discoloration for $\mathrm{Opal}{ }^{\circledR} \mathrm{Seal}^{\mathrm{TM}}{ }_{\text {-treated }}$ teeth which can no longer be reduced by polishing to reach levels below the clinically relevant threshold (Fig. 4b). 

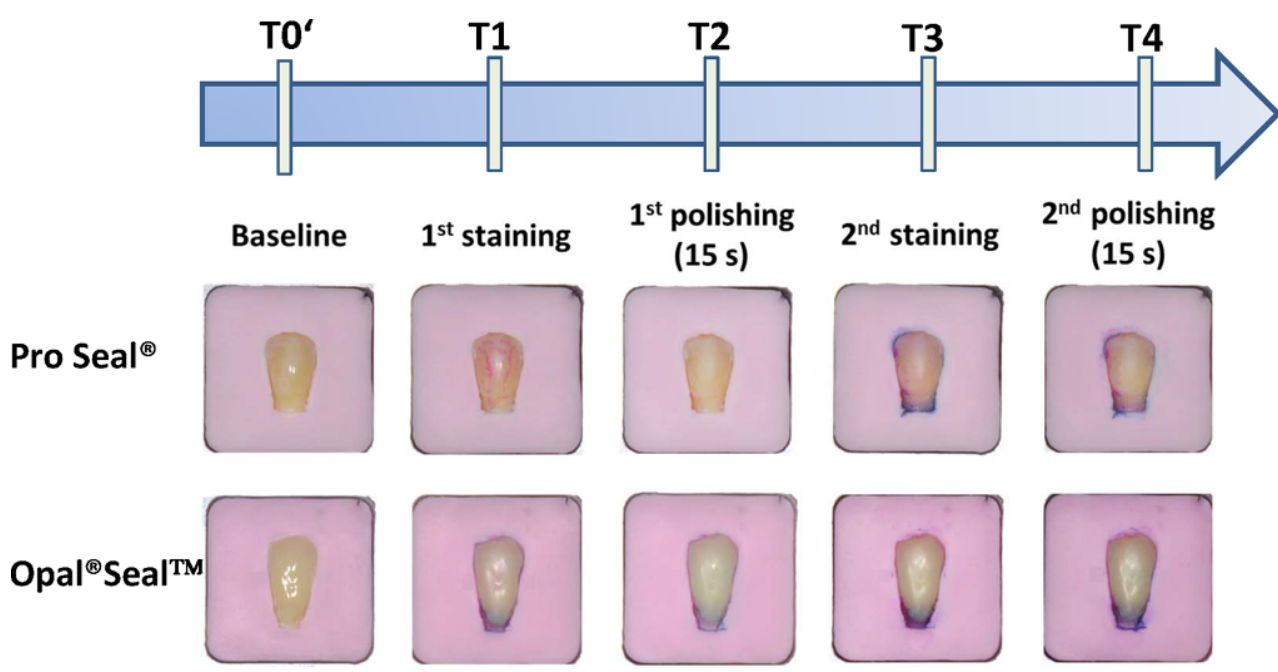

Fig. 3 Exemplary sample photographs. Each sample was evaluated after the application of surface sealant (T0', baseline), the first staining (T1), the first polishing for $15 \mathrm{~s}$ (T2), the second staining (T3) and second polishing for $15 \mathrm{~s}$ (T4). We found visible (clinically relevant) discoloration of sealant-treated tooth surfaces especially after the first staining of Pro Seal ${ }^{\circledR}$-treated teeth (T1), and the second staining (T3) and second polishing (T4) of both sealant materials

Abb. 3 Studienablauf anhand exemplarischer Darstellung von Proben. Die Farbe jeder Probe wurde nach dem Auftragen von Glattflächenversiegler (T0', Baseline), der ersten Färbung (T1), dem ersten Polieren für 15 s (T2), der zweiten Färbung (T3) und dem zweiten Polieren für 15s (T4) bestimmt. Wir fanden sichtbare (klinisch relevante) Verfärbungen der mit Glattflächenversieglern behandelten Zahnoberflächen, insbesondere nach der ersten Färbung der mit Pro Seal ${ }^{\circledR}$ behandelten Zähne (T1), der zweiten Färbung (T3) und dem zweiten Polieren (T4) beider Versieglermaterialien

\section{Comparison of color changes between the two surface sealants}

For comparison the mean color changes ( $\Delta \mathrm{E}$ values) for both surface sealants are depicted as box plots in Fig. 5 .

Significant differences of mean $\Delta \mathrm{E}$ values were detected between both sealants at both staining time points. Compared to Pro Seal ${ }^{\circledR}$-treated teeth, Opal ${ }^{\circledR} S e a l^{\mathrm{TM}}$-treated teeth showed less discoloration after the application of disclosing solution. Unlike Pro Seal ${ }^{\circledR}$-treated teeth discoloration of Opal ${ }^{\circledR S}$ Seal ${ }^{\mathrm{TM}}$-treated teeth could be reduced below clinically relevant levels by polishing. The second staining caused a discoloration on Pro Seal ${ }^{\circledR}$-treated teeth that was comparable to the one after the first staining. In contrast, the second staining on $\mathrm{Opal}^{\circledR} \mathrm{Seal}{ }^{\mathrm{TM}}$-treated teeth caused significantly more discoloration than the first staining. Moreover, after the second polishing, $\Delta \mathrm{E}$ values of $\mathrm{Opal}^{\circledR} \mathrm{Seal}^{\mathrm{TM}}$-treated teeth were slightly higher than those of Pro Seal ${ }^{\circledR}$-treated teeth, suggesting a progressive increase of discoloration of Opal ${ }^{\circledR} S e a l^{\mathrm{TM}}$-treated teeth which cannot be reduced by polishing.

Table 1 The means of $\mathrm{L}^{*}, \mathrm{a}^{*}, \mathrm{~b}^{*}$ and $\Delta \mathrm{E}$ values ( \pm standard deviation) for baseline after the application of surface sealant and staining and polishing conditions on sealed tooth surfaces

Tab. 1 Mittelwerte der $L^{*}-$, $\mathrm{a}^{*_{-}}, \mathrm{b}^{*}$ - und $\Delta \mathrm{E}-$ Werte ( \pm Standardabweichung) für die Messzeitpunkte der Studie: Baseline, nach dem Auftragen von Glattflächenversieglern sowie nach Färbe- und Polierbedingungen auf versiegelten Zahnoberflächen

\begin{tabular}{llllll}
\hline Material & Condition & $L^{*}$ & $a^{*}$ & $b^{*}$ & $\Delta \mathrm{E}$ (vs. baseline) \\
\hline $\begin{array}{l}\text { Pro Seal }{ }^{\circledR} \\
(n=48)\end{array}$ & Baseline & $86.19 \pm 4.15$ & $1.62 \pm 0.82$ & $29.35 \pm 3.2$ & 0 \\
& $1^{\text {st }}$ staining & $78.89 \pm 4.04$ & $10.38 \pm 4.28$ & $20.11 \pm 4.03$ & $15.57 \pm 4.87$ \\
& $1^{\text {st }}$ polishing & $84.97 \pm 3.99$ & $2.31 \pm 1.09$ & $25.18 \pm 3.10$ & $4.96 \pm 2.35$ \\
& $2^{\text {nd }}$ staining & $77.78 \pm 3.69$ & $6.67 \pm 2.98$ & $17.06 \pm 3.56$ & $16.17 \pm 4.73$ \\
& $2^{\text {nd }}$ polishing & $84.23 \pm 3.60$ & $1.35 \pm 1.40$ & $25.43 \pm 3.56$ & $5.56 \pm 3.63$ \\
Opal ${ }^{\circledR S}$ Seal ${ }^{T M}$ & Baseline & $84.76 \pm 4.54$ & $1.19 \pm 0.74$ & $29.51 \pm 2.98$ & 0 \\
& $1^{\text {st }}$ staining & $81.58 \pm 4.03$ & $2.05 \pm 1.27$ & $26.24 \pm 2.73$ & $5.17 \pm 2.92$ \\
& $1^{\text {st }}$ polishing & $83.21 \pm 4.13$ & $1.31 \pm 0.79$ & $26.95 \pm 3.1$ & $3.73 \pm 2.59$ \\
& $2^{\text {nd }}$ staining & $79.66 \pm 3.81$ & $-0.08 \pm 2.4$ & $24.64 \pm 2.66$ & $8.11 \pm 4.33$ \\
& $2^{\text {nd }}$ polishing & $82.12 \pm 4.45$ & $-0.85 \pm 1.77$ & $26.63 \pm 2.78$ & $6.61 \pm 4.62$ \\
\hline
\end{tabular}

Clinically relevant threshold $\Delta \mathrm{E}: 3.77$ 

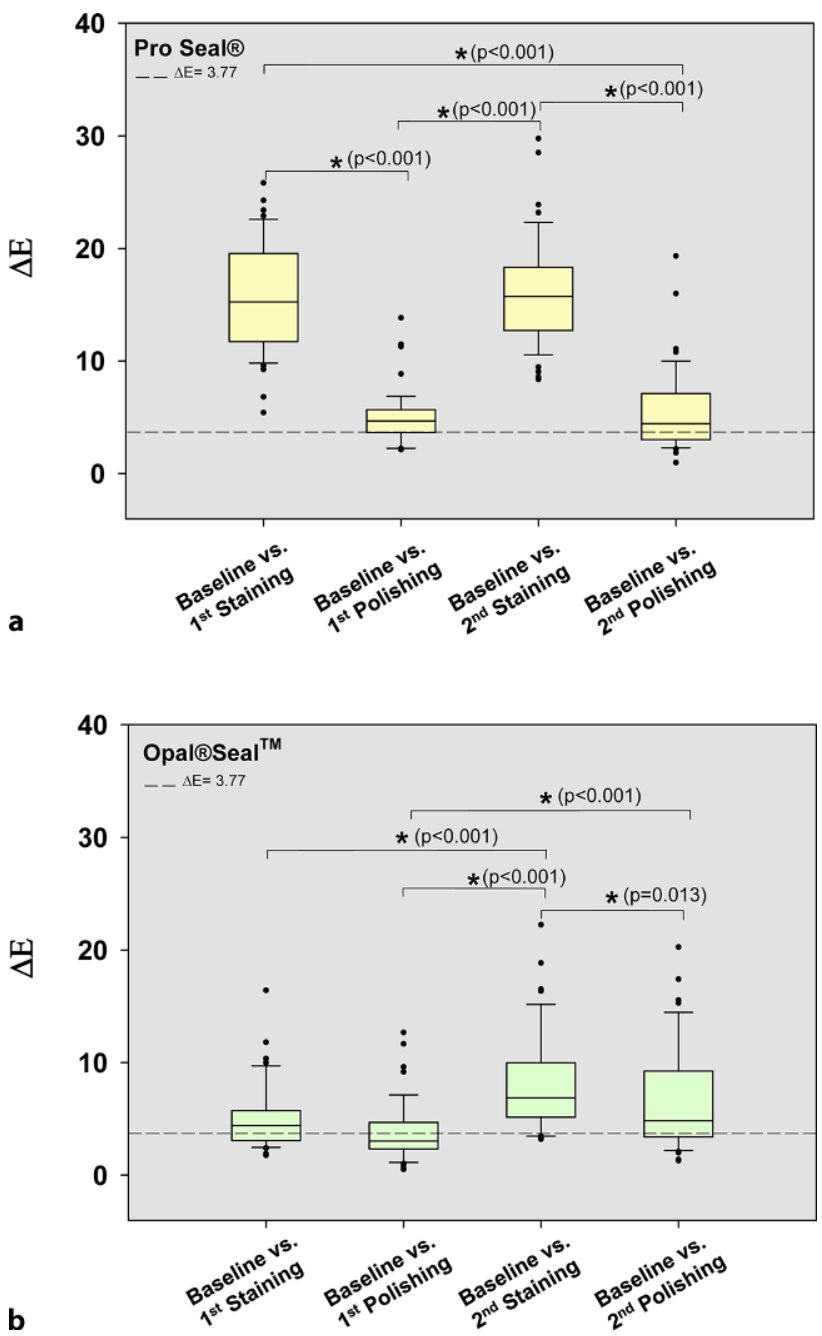

Fig. 4 Color changes within the sealant group. a In Pro Seal ${ }^{\circledR}$-treated teeth, $\Delta \mathrm{E}$ values for $\mathrm{T} 2$ vs. $\mathrm{T} 1, \mathrm{~T} 3 \mathrm{vs}$. T2, T4 vs. T3 and T4 vs. T1 were statistically significant $(* p<0.05$; Mann-Whitney U test). At all staining and polishing time points (T1-T4) color changes compared to baseline (T0') were above the clinically relevant threshold $\Delta \mathrm{E}=3.77$. b In Opal ${ }^{\circledR S e a l}{ }^{\mathrm{TM}}$-treated teeth, $\Delta \mathrm{E}$ values for $\mathrm{T} 3$ vs. T1, T3 vs. T2, and T4 vs. T2 were statistically significant $\left({ }^{*} p<0.05\right.$; Mann-Whitney $\mathrm{U}$ test). Except for T2, the values were above the clinically relevant threshold value

Abb. 4 Farbveränderungen innerhalb der Glattflächenversieglermaterialien. a Bei den mit Pro Seal ${ }^{\circledR}$ behandelten Zähnen waren die Werte von $\Delta \mathrm{E}$ für $\mathrm{T} 2$ vs. $\mathrm{T} 1, \mathrm{~T} 3$ vs. $\mathrm{T} 2, \mathrm{~T} 4$ vs. T3 und $\mathrm{T} 4$ vs. T1 statistisch signifikant $\left({ }^{*} p<0,05\right.$; Mann-Whitney-U-Test). Bei allen Färbeund Polierzeitpunkten (T1-T4) lagen die Farbveränderungen im Vergleich zum Ausgangswert (T0') über der klinisch relevanten Schwelle $(\Delta \mathrm{E}=3,77)$. b Bei mit Opal ${ }^{\circledR} S e a{ }^{\mathrm{TM}}$ behandelten Zähnen waren die Werte von $\Delta \mathrm{E}$ für T3 vs. T1, T3 vs. T2 und T4 vs. T2 statistisch signifikant ( ${ }^{*} p<0,05$; Mann-Whitney-U-Test). Mit Ausnahme von T2 lagen die $\Delta \mathrm{E}$-Werte über dem klinisch relevanten Schwellenwert

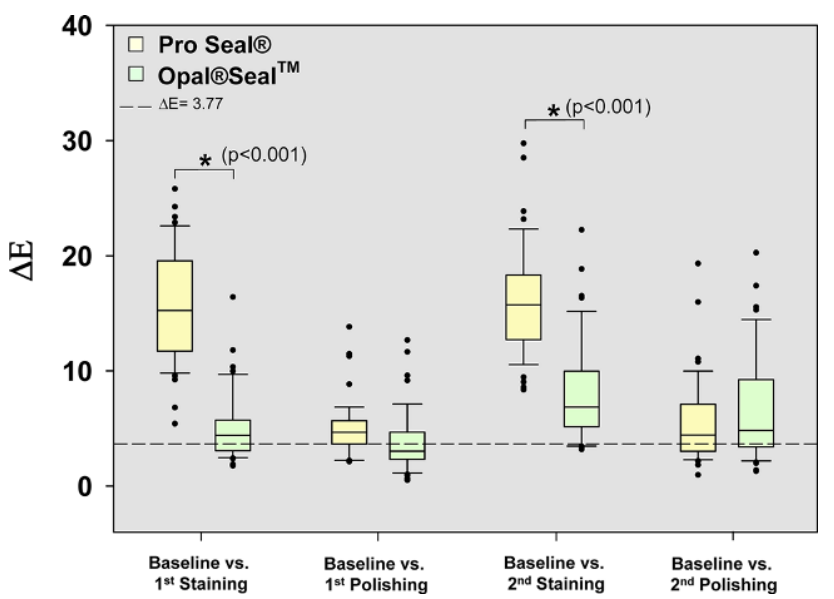

Fig. 5 Comparison of color changes between the sealant groups. $\Delta \mathrm{E}$ values of Pro $\mathrm{Seal}^{\circledR}{ }_{-}$or $\mathrm{Opal}^{\circledR} \mathrm{Seal}^{\mathrm{TM}}$-treated teeth were significantly different after each staining vs. baseline. After the first polishing $\Delta \mathrm{E}$ values were reduced below the clinically relevant threshold $(\Delta E=3.77)$ in $\mathrm{Opal}^{\circledR}{ }^{\circledR} \mathrm{Seal}^{\mathrm{TM}}$-treated teeth, but not in Pro Seal ${ }^{\circledR}$-treated teeth. Interestingly, after second polishing $\Delta \mathrm{E}$ values of $\mathrm{Opal}^{\circledR}{ }^{\circledR} \mathrm{Seal}{ }^{\mathrm{TM}}$-treated teeth remained higher than those of Pro Seal ${ }^{\circledR}$-treated teeth $\left({ }^{*} p<0.05\right.$; Mann-Whitney U test)

Abb. 5 Vergleich der Farbveränderungen zwischen den Glattflächenversieglermaterialien. Die $\Delta$ E-Werte der mit Pro Seal ${ }^{\circledR}$ - bzw. mit Opal ${ }^{\circledR S}$ Seal ${ }^{\mathrm{TM}}$ behandelten Zähne waren nach jeder Verfärbung signifikant unterschiedlich im Vergleich zum Ausgangswert. Nach der ersten Politur lagen die $\Delta \mathrm{E}-$ Werte bei den mit Opal ${ }^{\circledR} S e a l^{\mathrm{TM}}$ behandelten Zähnen unterhalb des klinisch relevanten Schwellenwerts $(\Delta \mathrm{E}=3,77)$, dies galt jedoch nicht für die mit Pro Seal ${ }^{\circledR}$ behandelten Zähne. Interessanterweise blieben nach der zweiten Politur die $\Delta \mathrm{E}$-Werte der mit Opal ${ }^{\circledR S}$ Seal ${ }^{\mathrm{TM}}$ behandelten Zähne höher als die der mit Pro Seal ${ }^{\circledR}$ behandelten Zähne $\left({ }^{*} p<0,05\right.$; Mann-Whitney-U-Test)

\section{Discussion}

This in vitro study aimed at mirroring the clinical setting as closely as possible. The study was performed using the experience of research group with the standardized preparation of tooth samples as well as with the application and durability of orthodontic surface sealants and the use of the plaque disclosing solution as a staining agent from our previous studies $[4,5,16]$. A clinically approved intraoral spectrophotometer of high reliability was used for the in vitro and in vivo measurements of color changes $[9,10$, 19].

Orthodontic surface sealants are prone to discoloration, for instance, by foods and beverages [5]. In high-risk orthodontic patients wearing fixed appliances with low compliance, such surface sealants are frequently used as a preventive measure to avoid tooth demineralization and white spot lesions. Due to their low compliance, these patients require regular professional tooth cleaning, which is often preceded by staining with a plaque disclosing solution. Such solutions, however, contain relatively high concentrations of various plaque staining dyes which might lead to discoloration of the orthodontic surface sealants caus- 
ing esthetic impairments. We have therefore evaluated the discoloration of the popular orthodontic surface sealants Pro Seal ${ }^{\circledR}$ and Opal ${ }^{\circledR}$ Seal ${ }^{\mathrm{TM}}$ by the commonly used twotone erythrosine-free disclosing dye solution Mira-2-Ton ${ }^{\circledR}$ in vitro on extracted teeth. In addition, we investigated whether Mira-2-Ton ${ }^{\circledR}$-dependent discoloration of Pro Seal ${ }^{\circledR}$ and Opal ${ }^{\circledR}$ Seal ${ }^{\mathrm{TM}}$ can be removed by polishing with brush and prophy paste during professional tooth cleaning. During treatment with fixed appliances, professional tooth cleaning is usually performed several times. Thus, in order to detect possible changes in the staining behavior of the sealers over time, we performed staining and polishing twice.

Both surface sealants, after the first staining, showed clinically relevant, visible discoloration. The extent of discoloration, however, was significantly higher in Pro Seal ${ }^{\circledR}$ treated teeth. Polishing reduced the color changes of Pro Seal ${ }^{\circledR}$-treated teeth significantly but discoloration remained clinically relevant. Discoloration of $\mathrm{Opal}{ }^{\circledR} \mathrm{Seal}^{\mathrm{TM}}$-treated teeth was only slightly reduced by polishing; however, due to the lower initial discoloration, color changes were lowered below the clinically relevant threshold. The second staining and polishing of Pro Seal ${ }^{\circledR}$-treated teeth was comparable with the results of the first staining. In contrast, Opal ${ }^{\circledR}$ Seal ${ }^{\mathrm{TM}}$-treated teeth, after the second staining and polishing, showed significantly higher discoloration than after the first staining and polishing so that, as with Pro Seal ${ }^{\circledR}$-treated teeth, clinically relevant discolorations remained. Our observations therefore showed that the extent of discoloration increased progressively on $\mathrm{Opal}^{\circledR} \mathrm{Seal}^{\mathrm{TM}}$ treated teeth.

In vitro, plaque disclosing solution caused discoloration of surface sealant-treated teeth which could not be sufficiently removed by professional tooth cleaning; thus, the null hypothesis was rejected.

A possible reason for the observed increase of discoloration of $\mathrm{Opal}^{\circledR} \mathrm{Seal}^{\mathrm{TM}}$ could be due to the different composition of the surface sealants. While Pro Seal ${ }^{\circledR}$ has a filler content of $18 \%$, $\mathrm{Opal}^{\circledR}{ }^{\circledR} \mathrm{Seal}{ }^{\mathrm{TM}}$ is a $38 \%$ filled sealant. Premaraj et al. compared the mechanical properties of Pro Seal ${ }^{\circledR}$ and $\mathrm{Opal}{ }^{\circledR} \mathrm{Seal}^{\mathrm{TM}}$ by performing scanning electron microscope analyses and optical profilometer measurements. Opal ${ }^{\circledR} S e a l^{\mathrm{TM}}$ was found to contain filler particles $(>250 \mathrm{~nm})$ more than 2.5 -fold the size of the particles in Pro Seal ${ }^{\circledR}(<100 \mathrm{~nm})$. Polishing with brush and prophy paste of Opal ${ }^{\circledR}$ Seal ${ }^{\mathrm{TM}}$ also caused high wear. This was explained by the authors through the abrasive contribution of the larger particles released by polishing of Opal ${ }^{\circledR} S e a \mathrm{I}^{\mathrm{TM}}$. This high abrasion leads to an increased surface roughness due to the loss of relatively large filler particles, which might have contributed to the increased discoloration by the plaque disclosing solution observed after polishing of $\mathrm{Opal}^{\circledR}{ }^{\circledR e a l^{\mathrm{TM}}}{ }^{2}$ surfaces.
In addition to surface roughness, penetration depths of the plaque disclosing dyes could have also contributed to changes in the discoloration properties observed for $\mathrm{Opal}^{\circledR}{ }^{\circledR} \mathrm{Sea}{ }^{\mathrm{TM}}$. We previously showed that abrasion from polishing of Pro Seal ${ }^{\circledR}$ and Opal ${ }^{\circledR S}$ Seal ${ }^{\mathrm{TM}}$ with brush and prophy paste were comparable (about $2-3 \mu \mathrm{m} / \mathrm{s}$ at vertical loads of $250 \mathrm{~N}$ ) [16]. Abrasion was also comparable at vertical loads of $150 \mathrm{~N}$ used in this study, albeit smaller $(0.5-0.8 \mu \mathrm{m} / \mathrm{s}$, data not shown).

Since the abrasion of both surface sealants was comparable, it is likely that after the first polishing the penetration depth of the plaque disclosing dye is higher in Opal ${ }^{\circledR} \mathrm{Seal}^{\mathrm{TM}}$ than in Pro Seal ${ }^{\circledR}$, so that abrasion during polishing for $15 \mathrm{~s}$ was too small to completely remove the stained layers of $\mathrm{Opal}^{\circledR} \mathrm{Seal}{ }^{\mathrm{TM}}$ to significantly reduce color changes. The penetration depth of plaque disclosing dyes, thus, appears to be larger than that of coffee and red wine which occurs in the superficial layer (depth $<20 \mu \mathrm{m}$ ) and can easily be removed by polishing [1].

Despite the observed reduction of color changes after the polishing, staining of both surface sealants was still visible. This should be considered when plaque staining is to be performed on teeth treated with these widely used orthodontic surface sealants. At the same time, it should be taken into account that the increased polishing required by the staining from plaque disclosing solutions can lead to further wear and thus to a loss of function of the surface sealants.

However, it must also be clearly stated here that the in vitro studies carried out here have numerous limitations with regard to the natural situation of the oral cavity and the transferability to the situation in the patient can therefore not be completely given. For instance, we cannot make any statement about the extent to which saliva and the proteins [11] it contains could affect the staining by plaque disclosing solutions. This also holds true for the potential impacts of nutrition, e.g., by cold or hot drinks, fruit juices or lemonades with acidic $\mathrm{pH}$ or abrasive foods. Furthermore, we have also not tested the influence of daily dental hygiene on discoloration of surface sealant-treated teeth by plaque disclosing solutions.

Thus, clearly further in vivo studies are necessary to fully investigate the extent of discoloration by plaque disclosing solutions and polishing dependent wear of orthodontic surface sealants.

\section{Conclusions}

Surface sealants show clinically relevant discoloration after exposure to plaque disclosing solution under in vitro conditions. Such discolorations could not be removed by professional tooth cleaning. Thus, in clinical practice plaque 
disclosing solutions might cause esthetic deficits in surface sealant-treated teeth, the impact of plaque disclosing solutions under clinical conditions (e.g., in the presence of saliva and by various aspects of a person's nutrition) should be investigated in clinical studies.

In the present in vitro investigation the following conclusions can be drawn with respect to discoloration of surface sealants.

- Both Opal ${ }^{\circledR}$ Seal ${ }^{\mathrm{TM}}$ and Pro Seal ${ }^{\circledR}$ showed significant and clinically relevant discoloration after staining with a plaque disclosing solution.

- Polishing was not sufficient to reduce discoloration to clinically irrelevant values.

- In vitro, plaque disclosing solutions caused discoloration of surface sealant treated teeth; we suggest that this might be taken into account when using them in vivo.

Acknowledgements We gratefully appreciate the financial support from the Wissenschaftsfond of the German Society of Orthodontics (DGKFO 113/1016) and from the Physician Scientist Fellowship Program of the Medical Faculty of the University of Heidelberg to Sinan Sen.

Funding Open Access funding provided by Projekt DEAL.

\section{Compliance with ethical guidelines}

Conflict of interest S. Şen, R. Erber, G. Şen, N. Deurer, S. Zingler and C.J. Lux declare that they have no competing interests.

Ethical standards The study protocol, including the use of extracted human teeth, was approved and the study was conducted in accordance with the guidelines set by the Ethics Committee for human studies at the Medical Faculty, University of Heidelberg (approval no. \#S301/2011). Before extraction, all participants or their parents or legal guardians received full oral and written information on the aims of the study and signed a consent form.

Open Access This article is licensed under a Creative Commons Attribution 4.0 International License, which permits use, sharing, adaptation, distribution and reproduction in any medium or format, as long as you give appropriate credit to the original author(s) and the source, provide a link to the Creative Commons licence, and indicate if changes were made. The images or other third party material in this article are included in the article's Creative Commons licence, unless indicated otherwise in a credit line to the material. If material is not included in the article's Creative Commons licence and your intended use is not permitted by statutory regulation or exceeds the permitted use, you will need to obtain permission directly from the copyright holder. To view a copy of this licence, visit http://creativecommons.org/licenses/by/4. $0 \%$

\section{References}

1. Anfe TE, Agra CM, Vieira GF (2011) Evaluation of the possibility of removing staining by repolishing composite resins submitted to artificial aging. J Esthet Restor Dent 23:260-267. https://doi.org/ 10.1111/j.1708-8240.2011.00435.x
2. Carter EC, Schanda JD, Hirschler R, Jost S, Luo MR, Melgosa M, Ohno Y, Pointer MR, Rich DC, Vienot F, Whitehead L, Wold JH, (2018) Vienna. International Commission on I. CIE 015:2018 Colorimetry, 4th ed

3. Checchi L, Montevecchi M, Gatto RM, Moreschi A, Checchi V (2007) Clinical efficacy of two toothbrushes with different bristles. Int J Dent Hyg 5:242-246. https://doi.org/10.1111/j.1601-5037. 2007.00258.x

4. Corcodel N, Hassel AJ, Sen S, Saure D, Rammelsberg P, Lux CJ, Zingler S (2017) Effect of enamel sealants on tooth bleaching and on the color stability of the result. Odontology 105:155-161. https://doi.org/10.1007/s10266-016-0253-6

5. Corcodel N, Hassel AJ, Sen S, Saure D, Rammelsberg P, Lux CJ, Zingler S (2018) Effects of staining and polishing on different types of enamel surface sealants. J Esthet Restor Dent 30:580-586. https://doi.org/10.1111/jerd.12423

6. Erbe C, Alhafne A, Jahn A, Wehrbein H (2013) Glattflächenversiegler in der kieferorthopädischen Praxis - eine Umfrage zu Häufigkeiten, Anwendung und Kontrolle. 86 Wissenschaftliche Jahrestagung der deutschen Gesellschaft für Kieferorthopädie Abstractband: 91 (P 40)

7. Guo J, Wu H, Du L, Fu Y (2013) Determination of Brilliant Blue FCF in food and cosmetic samples by ionic liquid independent disperse liquid-liquid micro-extraction. Anal Methods 5:4021-4026. https://doi.org/10.1039/C3AY40362A

8. Johnston WM (2009) Color measurement in dentistry. J Dent 37(Suppl 1):e2-e6. https://doi.org/10.1016/j.jdent.2009.03.011

9. Kim HK (2018) Evaluation of the repeatability and matching accuracy between two identical intraoral spectrophotometers: an in vivo and in vitro study. J Adv Prosthodont 10:252-258. https://doi.org/ 10.4047/jap.2018.10.3.252

10. Klotz AL, Habibi Y, Corcodel N, Rammelsberg P, Hassel AJ, Zenthofer A (2018) Laboratory and clinical reliability of two spectrophotometers. J Esthet Restor Dent. https://doi.org/10.1111/jerd. 12452

11. Lee YK, Powers JM (2006) Influence of salivary organic substances on the discoloration of esthetic dental materials-a review. J Biomed Mater Res 76:397-402. https://doi.org/10.1002/jbm.b. 30380

12. Manojlovic D, Lenhardt L, Milicevic B, Antonov M, Miletic V, Dramicanin MD (2015) Evaluation of staining-dependent colour changes in resin composites using principal component analysis. Sci Rep 5:14638. https://doi.org/10.1038/srep14638

13. Migliorati M, Isaia L, Cassaro A, Rivetti A, Silvestrini-Biavati F, Gastaldo L, Piccardo I, Dalessandri D, Silvestrini-Biavati A (2015) Efficacy of professional hygiene and prophylaxis on preventing plaque increase in orthodontic patients with multibracket appliances: a systematic review. Eur J Orthod 37:297-307. https://doi. org/10.1093/ejo/cju044

14. Nagashima Y, Shigeishi H, Fukada E, Amano H, Urade M, Sugiyama M (2018) Self-check with plaque disclosing solution improves oral hygiene in schoolchildren living in a children's home. Arch Public Health 76:50. https://doi.org/10.1186/s13690018-0296-y

15. Pretty IA, Edgar WM, Smith PW, Higham SM (2005) Quantification of dental plaque in the research environment. J Dent 33:193-207. https://doi.org/10.1016/j.jdent.2004.10.017

16. Sen S, Erber R, Kunzmann K, Kirschner S, Weyer V, Schilling L, Brockmann MA, Rues S, Orhan G, Lux CJ, Zingler S (2018) Assessing abrasion of orthodontic surface sealants using a modified ophthalmic optical coherence tomography device. Clin Oral Invest 22:3143-3157. https://doi.org/10.1007/s00784-018-2410-5

17. Versteeg PA, Rosema NA, Timmerman MF, Van der Velden U, Van der Weijden GA (2008) Evaluation of two soft manual toothbrushes with different filament designs in relation to gingival abrasion and 
plaque removing efficacy. Int J Dent Hyg 6:166-173. https://doi. org/10.1111/j.1601-5037.2008.00298.x

18. Volgenant CMC, Fernandez YMM, Rosema NAM, van der Weijden FA, Ten Cate JM, van der Veen MH (2016) Comparison of red autofluorescing plaque and disclosed plaque-a cross-sectional study. Clin Oral Invest 20:2551-2558. https://doi.org/10.1007/ s00784-016-1761-z

19. Zenthofer A, Cabrera T, Corcodel N, Rammelsberg P, Hassel AJ (2014) Comparison of the easyshade compact and advance in vitro and in vivo. Clin Oral Invest 18:1473-1479. https://doi.org/10. 1007/s00784-013-1118-9
20. Zimmer S, Barthel CR, Coffman L, Raab WH, Hefferren JJ (2005) Evaluation of dentin abrasion during professional tooth cleaning in an in vitro model. J Clin Periodontol 32:947-950. https://doi.org/ 10.1111/j.1600-051X.2005.00764.X

21. Zingler S, Matthei B, Kohl A, Saure D, Ludwig B, Diercke K, Lux CJ, Erber R (2015) In vitro studies on the cytotoxic potential of surface sealants. J Orofac Orthop 76:66-78. https://doi.org/ $10.1007 / \mathrm{s} 00056-014-0269-\mathrm{x}$ 